\title{
Iron overload measurements by CMR in patients with suspected hemochromatosis - comparison of methods for T2* calculation in myocardium and liver \author{
Roberto Blasbalg² and Dany Jasinowodolinski²
} \\ Carlos E Rochitte*1, Leonardo Sara1, Afonso A Shiozaki1, Gilberto Szarf,
}

\author{
Address: ${ }^{1}$ Fleury Medicina e Saúde and Heart Institute-InCor-University of São Paulo Medical School, São Paulo, Brazil and ${ }^{2}$ Fleury Medicina e \\ Saúde, São Paulo, Brazil \\ * Corresponding author
}

from 13th Annual SCMR Scientific Sessions

Phoenix, AZ, USA. 21-24 January 2010

Published: 21 January 2010

Journal of Cardiovascular Magnetic Resonance 2010, I 2(Suppl I):P285 doi:10.I I86/I532-429X-I2-SI-P285

This abstract is available from: http://jcmr-online.com/content/I2/SI/P285

(C) 2010 Rochitte et al; licensee BioMed Central Ltd.

\section{Introduction}

Iron tissue overload can be detected non-invasively by CMR using T2* measurements techniques. Hemochromatosis is a disorder of iron metabolism that results in excess iron accumulation in tissues and organs. If left undiagnosed and untreated, iron overload can cause serious, sometimes fatal health problems. Early detection of iron overload and hemochromatosis treatment can prevent complications and prolong life.

\section{Purpose}

Our objective was to investigate $\mathrm{T} 2 *$ measurements in patients with suspected hemochromatosis and to compare different approaches on $\mathrm{T} 2 *$ calculation for the myocardium and liver.

\section{Methods}

We evaluated 42 consecutive patients with suspected hemochromatosis using CMR in a 1.5 T GE HDx scanner. We performed breath-hold fast GRE sequence on a shortaxis view (including liver tissue in the same image) with several in-phase TEs(from 27.6 to $4.2 \mathrm{~ms}$ ) and fixed TR of $31 \mathrm{~ms}$ to calculate $\mathrm{T} 2 *$ for the liver and myocardium using both, the entire signal intensity (SI) curve (T2* = 1/exp) and only 2 points (9.6 and $4.2 \mathrm{~ms}$ ) with the following equation:-((9.6-4.2)/LN(SI @9.6/SI@4.2)). We will call them curve and formula $\mathrm{T} 2{ }^{*}$ calculations, respectively. For the liver iron overload we also used the technique described by Rennes University, described in detail elsewhere http://www.radio.univ-rennes1.fr/Sources/EN/ HemoTech.html.

\section{Results}

From the 42 patients with suspected hemochromatosis, 14 had a mutation of HFE gene detected (more commonly heterozygosis of $\mathrm{C} 282 \mathrm{Y}$ or H63D). Mean serum ferritin level was $745.9 \pm 364.8 \mu \mathrm{g} / \mathrm{L}(\mathrm{Nl}<300$ for men and $<200$ for women). Mean myocardial T2* was $32.1 \pm$ 10.0 and $29.5 \pm 11.3 \mathrm{~ms}$ for curve and formula calculations, respectively $(\mathrm{p}=0.04)$. Mean liver $\mathrm{T} 2{ }^{*}$ was $15.5 \pm$ 6.8 and $15.2 \pm 8.1$ for curve and formula calculations, respectively $(\mathrm{p}=0.41)$. Both methods correlated well for myocardium $(\mathrm{r}=0.74, \mathrm{p}<0.001)$ and for liver $(\mathrm{r}=0.94$, $\mathrm{p}<0.001)$. For myocardium a better correlation was seen for the $\mathrm{T} 2 *<20 \mathrm{~ms}(\mathrm{r}=0.87, \mathrm{p}<0.001)$.

Bland-Altman analysis showed $\mathrm{T} 2 *$ mean difference of 2.6(CI 0.1-5.0) and 0.4 ms (CI -0.6-1.3) for myocardium and liver comparisons, respectively, between curve and formula calculations. Most of cases had mild liver iron overload by Rennes method, with mean T2* of $15.4 \pm 5.7$ and maximal $\mathrm{T} 2 *$ of $31.5 \mathrm{~ms}$ (below the normal value of $35 \mathrm{~ms}$ ), indicating good agreement. 


\section{Conclusion}

Measurements of $\mathrm{T}^{*}$ in patients with suspected hemochromatosis could detect all ranges of myocardial and liver iron overload, and thus contributing to clinical management. The different approaches of myocardial and liver $2_{2}^{*}$ calculations led to similar results, indicating that they could be used interchangeably. The 2 point formula approach could be a faster option for $\mathrm{T} 2 *$ image acquisition and calculation.

Publish with Bio Med Central and every scientist can read your work free of charge

"BioMed Central will be the most significant development for disseminating the results of biomedical research in our lifetime. " Sir Paul Nurse, Cancer Research UK

Your research papers will be:

- available free of charge to the entire biomedical community

- peer reviewed and published immediately upon acceptance

- cited in PubMed and archived on PubMed Central

- yours - you keep the copyright 